\title{
KEBUTUHAN KEDELAI DAN KAPASITAS PRODUKSI TAHU PADA PENGRAJIN TAHU DI KABUPATEN SUMEDANG
}

\author{
Dety Sukmawati*
}

\section{ABSTRAK}

Kedelal merupakan salah satu komoditl kebutuhan pokok masyarakat Indonesia. Hal int dikanenakan kedelai merupakan bahan baku pembuatan tempe dan tahu yang telah menjadi menu sehari-hari masyarakat Indonesia pada umumnya. Pertanian adalah mata pencaharian utama penduduk Kabupaten Sumedang. Selain daerah ini terkenal dengan hasil padi, sumedang penghasil palawija diantaranya kedelai yang banyak digunakan sebagat bahan baku tahu oleh sebagian besar penduduk Sumedang sebagai pengrajin tahu yang terdiri dari 232 pengrajin tahu. dari data Kabupaten Sumedang, kedelai dihasilkan pada 2 kecamatan, yaitu Kecamatan jatigede 309 ton dan Kecamatan Surian 233 ton, jumlah kedelat yang dihasilkan Kabupaten Sumedang adalah 542 ton, melihat kebutuhan kedelai pada pengrajin tahu per bulan $630.180 \mathrm{~kg}(630,180$ ton), maka produksi kedelai di Sumedang tidakmencukupi untuk memenuhi kelutuhan bahan baku tahu per bulan. Dari 26 kecamatan di Kabupaten Sumedang, henya 2 kecamatan daerah penghasil tanaman kedelai, disamping rendahnya daerah penghasil kedelai, kondisi seperti ini hampir terjadi di seluruh Indonesia, hal ini terjadi Dari segi persaingan pasar. ternyata harga ril kedelai impor jauh lebih murah daripada kedelai dalam produksi dalam negri. Selama harga kedelai impor rendah, maka anus impor akan semakin tinggi, sehingga harga kedelai produksi dalam negri akan turun, hal ini menyebabkan petani enggan untuk menanam kedelai. Peniorunan lisinga rill menjadi disinsentif yang menyebabkan terjadinya penumunan aneal kedelai.

Kata kunct: kedelai, kapasitas produksi, tahu, pengrajin tahu, impor. dalam negeri 


\section{PENDAHULUAN}

Indonesia dikenal sebagai negara agraris karena berkah kekayaan alam yang berlimpah, terutama di bidang sumber daya pertanian seperti lahan, varietas, dan iklim. Selain itu, Indonesia juga memiliki pengetahuan pertanian yang tersimpan dalam kearifan lokal dan kultur masyarakat. Dengan denikian komoditi pertanian sangat penting untuk diperhatikan, terutama komoditi-komoditi pertanian yang diolah menjadi kebutuhan pokok masyarakat. Kestabilan harga di pasar domestik dan keterjangkauan harga komoditi pokok seperti beras, tepung terigu, gula pasir, minyak goreng, dan kedelai oleh masyarakat kelas bawah merupakan indikator utama keberhasilan sebuah negara agraris. Oleh karena itu pergerakan harga kebutuhan pokok perlu terus dipantau. Berikut ini digambarkan pergerakan harga komoditi pokok tersebut berdasarkan data yang diperoleh dari Departemen Perdagangan:

\section{Tabel 1}

Perbandingan Harga Rata-Rata Nasional (Rp/Kg) Komoditif Kebutuhan Pokok hingga 6 Juni 2009

\begin{tabular}{|c|c|c|c|c|c|c|c|c|c|c|c|}
\hline \multirow{3}{*}{ No } & \multirow{3}{*}{ Komoditas } & \multicolumn{2}{|c|}{ Rata-rata } & \multirow{3}{*}{$\frac{30 \text { Juni }}{\text { Rp }}$} & \multirow{3}{*}{$\begin{array}{c}6 \text { Juli } \\
\operatorname{Rp}\end{array}$} & \multicolumn{6}{|c|}{ Perubahan } \\
\hline & & Apr & Mei & & & \multicolumn{2}{|c|}{$\begin{array}{c}\text { Aprke } \\
\text { 6-Jul }\end{array}$} & \multicolumn{2}{|c|}{$\begin{array}{c}\text { Mei ke } \\
\text { 6-Jul }\end{array}$} & \multicolumn{2}{|c|}{$\begin{array}{c}30 \text { Jun ke } \\
6-J u l\end{array}$} \\
\hline & & $\mathrm{Rp}$ & $\mathrm{Rp}$ & & & Rp & $R p$ & $R p$ & $R p$ & $\mathrm{Rp}$ & $R p$ \\
\hline 1 & Beras & 5.689 & 5.756 & 5.669 & 5.663 & -26 & -0.46 & -93 & -1.62 & -6 & -0.11 \\
\hline 2 & Tepung Terigu & 7.607 & 7.654 & 7.663 & 7.656 & 49 & 0.64 & 2 & 0.03 & -8 & -0.1 \\
\hline 3 & Gula Pasir Lokal & 8.046 & 8.406 & 8.507 & 8.485 & 440 & 5.46 & 80 & 0.95 & .22 & -0.26 \\
\hline 4 & Minyak Goreng Kemasan & 8.394 & 8.446 & 8.704 & 8.581 & 187 & 2.23 & 135 & 1.59 & -123 & -1.42 \\
\hline 5 & Minyak Goreng Curah & 9.42 & 10.014 & 9.440 & 9.303 & -116 & -1.23 & .710 & -7.09 & -136 & -1.44 \\
\hline 6 & Kedelai Impor & 8.095 & 8.047 & 7.914 & 7.957 & -138 & -1.71 & .90 & -1.12 & 43 & 0.55 \\
\hline 7 & Kedelai Lokal & 8.820 & 8.630 & 8.646 & 8.612 & -208 & -2.36 & -18 & -0.21 & -34 & -0.4 \\
\hline
\end{tabular}

Perkembangan harga sejumlah kebutuhan pokok hingga 6 Juli 2009 sebagai berikut. Pada seminggu terakhir kenaikan harga hanya terjadi pada komoditi pokok kedelai impor sebesar Rp. 43,- (0,55\%). Sedangkan penurunan harga terjadi pada komoditi beras sebesar Rp. $6,-(0,11 \%)$, tepung terigu sebesar Rp. 8,- (0,10\%), gula pasir lokal sebesar Rp. 22,$(0,26 \%)$, minyak goreng kemasan sebesar Rp. $123,-(1,42 \%)$, minyak goreng curah sebesar Rp. 136,- (1,44\%), dan kedelai lokal sebesar Rp. $34,-(0,40 \%)$. Dibandingkan dengan harga rata-rata bulan Mei 2009, maka komoditi pokok tepung terigu, gula pasir lokal dan mir.yak goreng kemasan mengalami kenaikan harga pada 6 Juli 2009. Penurunan harga terjadi pada komoditi beras, minyak goreng curah, kedelai impor dan kedelai lokal. Jika dibandingkan dengan harga rata-rata bulan April 2009, trend-nya 
sama dengan bulan Mei, yaitu komoditi pokok tepung terigu, gula pasir lokal dan minyak goreng kemasan mengalami kenaikan harga pada 6 Juli 2009. Penurunan harga terjadi pada komoditi beras, minyak goreng curah, kedelai impor dan kedelai lokal.

Harga kedelai impor telah membuat petani kita enggan untuk menanam kedelai. Kedelai lokal memang cenderung kalah bersaing dengan kedelai impor, baik dalam segi harga maupun kualitas. Dengan demikian petani merasa tidak mendapatkan insentif untuk menanam kedelai, apalagi tak ada jaminan harga pada saat musim panen kedelai telah tiba. Implikasinya adalah terjadi penurunan produksi kedelai dalam negeri, dan Indonesia semakin tergantung kepada kedelai impor. Jika demikian maka akan sulit bagi pemerintah Indonesia untuk menstabilkan harga kedelai dikarenakan kecielai impor sepenuhnya dikendalikan olch harga di pasar internasional.

Kedelai merupakan salah satu komoditi kebutuhan pokok masyarakat Indonesia. Hal ini dikarenakan kedelai merupakan bahan baku pembuatan tempe dan tahu yang telah menjadi menu sehari-hari masyarakat Indonesia pads umumnya. Untuk memenuhi kebutuhan masyarakat terhadap tahu dan tempe terscbut, pada saat ini terdapat 115.000 pengrajin tahu dan tempe di seluruh Indonesia berdasarkan data Sensus Ekonomi Nasional (Susenas) 2005 oleh Badan Pusat Statistik (BPS) (Ibnu Purna,2010). Kedelai scbagai bahan baku tempe dan tahu diperlukan di Kabupaten Sumedang yang merupakan penghasil talıu dengan jumlah pengrajin tahu 232 pengrajin pada data tahun 2009. hal ini mengindikasikan bahwa kebutuhan kedelai harus selalu tersedia di Kabupaten Sumedang.Berdasarkan hal tersebut perlunya diketahui kebutuhan kedelai dan kapasitas produksi tahu pada pengrajin tahu di Sumedang yang diperlukan untuk menentukan berapa banyak kebutuhan kedelai yang harus disediakan pada seluruh pengrajin tahu dan berapa banyak kedelai yang dihasilkan di daerah Kabupaten Sumedang, mengingat terjadi penurunan produksi dalam negri dan muralınya harga kedelai impor yang membuat petani enggan untuk menanam kedelai.

\section{PEMBAHASAN}

\section{Komoditi Kedelal}

Tanaman kedelai merupakan salah satu bahan pangan yang penting setelah beras disamping sebagai bahan pakan dan industri olahan. Karena hampir $90 \%$ digunakan sebagai bahan pangan maka ketersediaan kedelai 
menjadi faktor yang cukup penting (Anonimous, 2004c). Selain itu kedelai juga merupakan tanaman palawija yang kaya protein yang memiliki arti penting sebagai sumber sumber protein nabati untuk peningkatan gizi dan mengatasi penyakit kurang gizi seperti busung lapar. Perkembangan manfaat kedelai sebagai sumber protein, makanan berbahan kedelai dapat dipakai juga sebagai penurun cholesterol darah yang dapat mencegah penyakit jantung. Selain itu kedelai dapat berfungsi sebagai antioksidan dan dapat mencegah penyakit kanker. Oleh karena itu ke depan proyeksi kebutuhan kedelai akan meningkat seiring dengan kesadaran masyarakat tentang makanan sehat. Produk kedelai sebagai bahan olahan pangan berpotensi dan berperan menumbuhkembangkan industri kecil menengah bahkan komoditas ekspor (Simatupang, 2005).

Tanaman kedelai yang merupakan tanaman cash crop dibudidayakan di lahan sawah dan lahan kering. Sekitar $60 \%$ areal pertanaman kedelai terdapat di lahan sawah dan $40 \%$ lainnya di lahan kering. Benih bermutu varietas unggul merupakan salah satu faktor yang menentukan produktivitas pertanaman kedelai. Dalam mendukung pentediaan benih bermutu, industri benih di komoditas kedelai belum berkembang dengan bail. Produsen benih nasional maupun penangkar lokal masih kurang berperan (Siregar 1999 dalam Simatupang 2005) berbeda dengan komoditas padi dan jagung. Usaha perbenihan untuk tanaman kedelai masih tertinggal, petani lebih banyak memakai benih asalan atau turunan dari pertanaman sebelumnya. Industri pangan berupa tahu, tempe dan kecap banyak menyerap biji kedelai. Konsumsi tertinggi untuk bahan industri tahu dan tempe berdasarkan perhitungan, konsumsi kedelai untuk tahu dan tempe pada tahun 2002 mencapai 1,776 juta ton atau $88 \%$ dari total kebutuhan dalam negri digunakan sebagai bahan baku olahan tahu dan tempe (BPS 2002, Simatupang 2005). Industri pakan ternak (unggas) merupakan kegiatan agribisnis hilir yang cukup penting dalam agribisnis kedelai. Dalam pembuatan pakan ternak, bungkil kedelai merupakan bahan terpenting kedua setelah jagung, yaitu sekitar $15-20 \%$ dari komposisi pakan. Kedelai juga sebagai bahan baku penting industri lain, diantaranya tepung, olahan pangan dan pati. Namun kebutuhan industri lain ini hanya menyerap biji kedelai sekitar $12 \%$ dari total kebutuhan konsumsi kedelai.

\section{KEBUTUHAN KEDELAI}

Kebutuhan nasional untuk kedelai mencapai 2,2 juta ton per tahun. Namun demikian, baru 20 sampai 30 persen saja dari kebutuhan tersebut 
yang dapat dipenuhi oleh produksi dalam negeri. Sementara 70 sampai 80 persen kekurangannya, bergantung pada impor. Ketergantungan terhadap impor ini membuat instansi terkait sulit untuk mengontrol harga kedelai. Padahal kestabilan harga kedelai erat kaitannya dengan keberlangsungan usaha pengrajin tahu dan tempe di Indonesia.

Terdapat sejumlah permasalahan internal dan eksternal dalam tata niaga kedelai di Indonesia. Namun, yang mungkin dapat ditangani dengan cepat adalah permasalahan internal. Sementara permasalah eksternal sangat berkaitan dengan kebijakan perdagangan dunia oleh Organisasi Perdagangan Dunia (WTO) dan Dana Moneter Internasional (IMF).

Permasalahan di sisi internal, antara lain murahnya harga kedelai impor telah membuat petani kita enggan untuk menanam kedelai. Kedelai lokal memang cenderung kalah bersaing dengan kedelai impor, baik dalam segi harga maupun kualitas. Dengan demikian petani merasa tidak mendapatkan insentif untuk menanam kedelai, apalagi tak ada jaminan harga pada saat musim panen kedelai telah tiba. Implikasinya adalah terjadi penurunan produksi kedelai dalam negeri, dan Indonesia semakin tergantung kepada kedelai impor. Jika demikian maka akan sulit bagi pemerintah Indonesia untuk menstabilkan harga kedelai dikarenakan kedelai impor sepenuhnya dikendalikan oleh harga di pasar internasional.

Sebagai ilustrasi, pertumbuhan produksi kedelai nasional periode 2003 sampai dengan 2008 dibandingkan dengan pertumbuhan produksi pangan nabati lainnya. produksi kedelai pada tahun 2003 mencapai 672 juta ton, naik menjadi 723 juta ton pada 2004, dan naik lagi menjadi 808 juta ton (2005), kemudian turun menjadi 748 juta ton (2006), terus turun menjadi 593 juta ton (2007). Produksi kedelai pada tahun 2007 'sudah berada dibawah produksi kedelai pada tahun 2003 atau turun sebesar 79 juta ton. Namun untuk tahun 2008, produksi kedelai akan kembali naik menjadi 776 juta ton, karena berbagai terobosan yang dilakukan pemerintah, seperti perluasan areal tanam, pemberian bantuan benih maupun sarana produksi pertanian serta insentif bagi petani agar mereka bergairah menanam kedelai.

Dalam rangka mempertahankan peningkatan produksi kedelai, tentunya sangat diperlukan sejumlah kebijakan, antara lain: pertama, memperbaiki kualitas benih. Hal ini sangat diperlukan dalam rangka meningkatkan mutu untuk dapat bersaing dengan kedelai impor. Apabila kualitas benih sudah ditingkatkan, diharapkan mutu kedelai produksi dalam negeri juga akan 
meningkat. Jika mutu kedelai lokal telah bagus, maka secara otomatis pengrajin tahu dan tempe akan lebih memilihnya ketimbang kedelai impor. Disamping perbaikan kualitas benih, petani harus melakukan pemupukan tanaman sesuai aturan yang telah digariskan oleh Deptan. Untuk kedua kegiatan ini pemilihan benih yang unggul dan pemupukan sesuai aturan diperlukan bimbingan yang intensif olch aparat Deptan. Oleh karena itu Penyuluh Pertanian Lapangan (PPL) Deptan perlu lebih aktif mendampingi petani dalam bercocok tanam.

Kebijakan yang kedua adalah dengan memberikan jaminan harga. Kebijakan ini bisa dilaksanakan, misalnya dengan memberi peran yang lebih besar kepada Perum Bulog yaitu disamping sebagai penyalur juga sebagai stabilator harga. Dengan demikian petani kedelai tidak perlu khawatir akan mengalami kerugian akibat fluktuasi harga kedelai, terutama jatuhnya harga kedelai pada musim panen. Dan kebijakan yang ketiga adalah dengan membangun jaringan terpadu antara petani dan pengrajin tahu tempe sehingga akses terhadap kedelai lokal dapat maksimal dan ketergantungan terhadap kedelai impor dapat diminimalisir. Melalui ketiga kebijakan tersebut, diharapkan Indonesia dapat secara berangsur-angsur mengurangi ketergantungan terhadap kedelai impor dan selanjutnya dapat mencapai swasembada kedelai yang dapat menguntungkan semua pihak, khususnya pada petani kedelai dan industri yang menggunakan bahan baku kedelai (Ibnu Purna, 2010).

\section{KEBUTUHAN KEDELAI DAN KAPASITAS PRODUKSI TAHU}

Kabupaten Sumedang adalah salah satu kabupaten yang berada dibawah pemerintahan Propinsi Jawa Barat. kabupaten ini memiliki luas wilayah $1.522,2 \mathrm{Km} 2$ dengan 26 kecamatan yang ada didalamnya. Pertanian adalah mata pencaharian utama penduduk Kabupaten Sumedang. Selain daerah ini terkenal dengan hasil padi, sumedang penghasil palawija diantaranya kedelai yang banyak digunakan sebagai bahan baku tahu oleh sebagian besar penduduk sumedang sebagai pengrajin tahu yang terdiri dari 232 pengrajin tahu. Mengingat di pasar domestik kedelai berasal dari impor, periu mengetahui kebutuhan kedelai dan kapasitas produksi tahu pada pengrajin tahu dan produksi kedelai yang dihasilkan kabupaten Sumedang, sebagai gambaran hasil pertanian guna menunjang industri pengolahan selanjutnya. Adapun hal tersebut dapat dilihat pada Tabel 2. 
Tabel 2.

Kebutuhan Kedelai dan Kapasitas Produksi Tahu Pengrajin Tahu Per Kecamatan di Kabupaten Sumedang Tahun 2009.

\begin{tabular}{|c|c|c|c|}
\hline \multirow[b]{2}{*}{ Kecamatan } & \multicolumn{2}{|c|}{ Kebutuhan Kedalai $(\mathrm{Kg})$} & \multirow{2}{*}{$\begin{array}{c}\text { Kapasitas } \\
\text { Produksihar } \\
\text { (Ancak } 50 \times 50 \times 3 \text { ) }\end{array}$} \\
\hline & Per hari & Per bulan & \\
\hline Cimalaka & 450 & 11.000 & 200 \\
\hline Damaraja & 40 & 1200 & 20 \\
\hline Paseh & 180 & 5400 & 130 \\
\hline Situraja & 960 & 28.800 & 27.325 \\
\hline Tanjungsari & 1.848 & 91.890 & 1.531 .5 \\
\hline Sumedang Selatan & 200 & 6000 & 100 \\
\hline Wado & 5 & 150 & 2.5 \\
\hline Cibugel & 725 & 21.750 & 362,5 \\
\hline Taniunokerta & 445 & 13.350 & 222.5 \\
\hline Cimanggung & 1.805 & 54.150 & 902,5 \\
\hline Cisitu & 1.100 & 33.000 & 550 \\
\hline Conggeang & 810 & 24.300 & 405 \\
\hline Darmaraja & 310 & 93.000 & 155 \\
\hline Cikareo Wado & 100 & 3.000 & 50 \\
\hline Ganeas & 8 & 200 & 4 \\
\hline Jafigede & 165 & 4.750 & 82.5 \\
\hline Jafinangor & 180 & 5.400 & 90 \\
\hline Jatinungga! & 461 & 13.830 & 230,5 \\
\hline Pamulinan & 1.580 & 47.400 & 787,5 \\
\hline Tomo & 50 & 1.500 & 25 \\
\hline Ujung Jaya & 200 & 6.000 & 100 \\
\hline Sumedang Utara & 4.892 & 144.760 & 2.446 \\
\hline Wado & 455 & 7.650 & 227.5 \\
\hline sumlah & 22.065 .5 & 630.180 & $37.870,3$ \\
\hline Rata-rata & 959.4 & 27.399 & 1.646 .5 \\
\hline
\end{tabular}

Sumber : Cinas Perindustrian dan Perdagangan Kabupaten Sumedang,2009.(Diolah).

Dari data Kabupaten Sumedang, kedelai dihasilkan pada 2 kecamatan, yaitu Kecamatan jatigede 309 ton dan Kecamatan Surian 233 ton, jumlah kedelá yang dihasilkan Kabupaten Sumedang adalah 542 ton, melihat kebutuhan kedelai pada pengrajin tahu per bulan $630.180 \mathrm{~kg}(630,180 \mathrm{ton})$, 
maks produks kedelai di Sumedimg tidak mencukupi untuk memenuhi keburuhan bahan baku taliu per bulan. Kebutuban kedelai dipenubi dari kedelai impor hal ini dikarenakan rendalinya harga kedelai impor telah membuat petani kita enggan untuk menanam kedelai. Kedelai lokal memang cenderung kalah bersaing dengan kedelai impor, baik dalam segi harga maupun kualitas. Dengan demikian petani merasa tidak mendapatkan insentif unfuk menanam kedelai, apalagi tak ada jaminan harga pada saat musim panen kedelai,Implikasinya adalah terjadi penurunan produksi kedelai dalam negeri, dan I..Jonesia semakin tergantung kepada ledelai impor. Jika demikian maka akan sulit bagi pemerintah Indonesia untuk menstabilkan harga kedelai dikarenakan kedelai impor sepenuhnya dikendalikan oleh harga di pasar internasional.

Dari 26 kecamatan di Kabupaten Sumedang, hanya 2 kecamatan daerah penghasil tanaman kedelai, disamping rendahnya daerah penghasil kedelai, kondisi seperti ini hampir terjadi di seluruh Indonesia, hal ini terjadi Dari segi persaingan pasar, ternyata harga riil kedelai impor jauh Iebih muralı daripada kedelai dalam produksi dalam negri. Selama harga kedelai impor rendah, maka arus impor akan semakin tinggi, sehingga harga kedelai produksi dalam negri akan turun, hal ini menyebabkan petani enggan untuk menanam kedclai. Penurunan harga riil menjadi disinsentif yang menyebabkan terjadinya penurunan areal kedelai.

Studi daya saing yang pernah dilakukan Gonzales 1993 menunjukkan bahwa secara ekonomi usahatani kedelai di Indonesia belum mempunyai keunggulan komparatif dan kompetitif, baik yang dilakukan secara tradisional maupun secara komersial. Arah pengembangan komoditas kedelai agar memiliki daya saing yang tinggi adalah dengan meningkatkan produksı, memperbaiki kualitas dan dayaguna kedelai sebagai produk olahan dari bahan baku non kedelai lainnya. Disamping itu, kebijakan pemerintah yang dapat melindungi harga kedelai domestik dan kebijakan pemberlakuan tarif impor serta pembatasan jumlah impor. Harga kedelai hampir tidak tersentuh oleh kebijakan pemerintah. Harga kedelai ditentukan oleh mekanisme pasar, yang ditentukan oleh permintaan dan persediaan (Demand and Supply). Harga nominal kedelai di tingkat petani berfluktuasi, belum berlakunya tarif impor menyebabkan jumlah kedelai impor semakin banyak, schingga harga kedelai di dalam negri jatuh, oleh karena itu pengendalian impor dan pengamanan pasar dalam negri perlu ditingkatkan. 
Strategi peningkatan produksi kedelai ditempuh melalui program : a) Peningkatan produktivitas (PP) dan b) Perluasan areal tanam (PAT). Program peningkatan produktivitas diprioritaskan di wilayah-wilayah sentra produksi yang produktivitasnya tergolong rendah, dimana tingkat penerapan teknologi oleh petani masih kurang. Perluasan areal dapat dilakukan pada sawah tadah hujan/irigasi sederhana, dan lahan kering cukup luas, namun belum dimanfaatkan.

Prioritas agroekosistem sasaran pengembangan kedelai perl mempertimbangkan beberapa hal, yaitu kendala produksi yang minimal (tanah dan iklim ), peluang keberhasilan yang cukup tinggi, prasarana pendukung cukup baik dan ketersediaan SDM (petani) yang terampil. Untuk itu prioritas pertama adalah lahan swah irigasi, kedua lahan sawah tadah hujan dan ketiga adalah lahan-lahan kering (sudah pernah dibudiayakan. iklim /curah hujan mendukung, bukan lahan bukaan baru) (Simatupang, 2005).

\section{KESIMPULAN}

kedelai dihasilkan pada 2 kecamatan, yaitu Kecamatan jatigede 309 ton dan Kecamatan Surian 233 ton, jumlah kedelai yang dihasilkan Kabupaten Sumedang adalah 542 ton, melihat kebutuhan kedelai pada pengrajin tahu per bulan $630.180 \mathrm{~kg}$ (630,180 ton), maka produksi kedelai di Sumedang tidak mencukupi untuk memenuhi kebutuhan bahan baku tahu per bulan. Dari 26 kecamatan di Kabupaten Sumedang, hanya 2 kecamatan daerah penghasil tanaman kedelai, disamping rendahnya daerah penghasil kedelai, kondisi seperti ini hampir terjadi di seluruh Indonesia, hal ini terjadi Dari segi persaingan pasar, ternyata harga riil kedelai impor jauh lebih murah daripada kedelai dalam produksi dalam negri. Selama harga kedelai impor rendah, maka arus impor akan semakin tinggi, sehingga harga kedelai produksi dalam negri akan turun, hal ini menyebabkan petani enggan untuk menanam kedelai. Penurunan harga riil menjadi disinsentif yang menyebabkan terjadinya penurunan areal kedelai. oleh karena itu pengendalian impor dan pengamanan pasar dalam negri perlu ditingkatkan.

Strategi peningkatan produksi kedelai ditempuh melalui program : a) Peningkatan produktivitas (PP) dan b) Perluasan areal tanam (PAT). Program peningkatan produktivitas diprioritaskan di wilayah-wilayah 
sentra produksi yang produktivitasnya tergolong rendal, dimana tingkat penerapan teknologi oleh petani masih kurang. Perluasan areal dapat dilakukan pada sawah tadah hujan/irigasi sederhana, dan lahan kering cukup luas, namun belum dimanfaatkan.

\section{DAFTAR PUSTAKA}

Anonimous 2004 C.Rodmap Komoditas Kedelai. Balitkabi

Ibnu Purna. 2010. Upaya Peningkatan Produksi Kedelai. www.Setneg.Go.jd Simatupang,P, Marwoto, dan Dewa KS Swastika. 2005. Pengembangan Kedelai dan Kebijakan Penelitian di Indonesia. Makalah pada Lokakarya Pengembangan Kedelai di Lahan Sub Optimal di Balitkabi.Malang.

Kabupaten Sumedang dalam Angka. 2009.

*) Ir. Dety Sukmawatl, MP adalah dosen Kopertis Wilayah IV Jabar-Banten yang diperbantukan pada Jurusan Agribisnis Fakultas Pertanian Universitas Winaya Mukti.S1 dari jurusan Sosial Ekonomi Pertanian Sekolah Tinggi Pertanian Tanjungsari (UNWIM), dan S2 dari IImu Pembangunan Ekonomi Pertanian UNPAD. 